\title{
DECIDUOUS WINGS IN CRICKETS: A NEW BASIS FOR WING DIMORPHISM
}

\author{
By T. J. WALKeR ${ }^{1}$ \\ Department of Entomology and Nematology \\ University of Florida, Gainesville 3260I
}

Dimorphism in wing length occurs in species of at least seven insect orders (Richards, 196I). It is conspicuous in many species of crickets. Crickets with the folded metathoracic wings extending beyond the tegmina are termed macropterous, and those with the folded metathoracic wings covered by the tegmina are termed micropterous (Alexander, 1961, 1968). Since flying crickets - such as those flying to light traps - are always macropterous, it seems safe to conclude that micropterous crickets cannot fly. It seems probable, though the evidence is sparse, that macropterous individuals generally do fly and that wing dimorphism in crickets has the same behavioral correlation with emigration that it has in aphids (Kennedy and Stroyan, 1959).

In studying three species of short-tailed cricket (Anurogryllus) ${ }^{2}$, I noted dimorphism in wing length. Most specimens had no visible metathoracic wings (i.e. were micropterous), but $5 \%$ of those of the U. S. species and about $20 \%$ each of two West Indian species had conspicuously protruding metathoracic wings (i.e. were macropterous). At least 5 of the 16 macropterous West Indian specimens were collected at light, but none of the 4 macropterous specimens of the U.S. species were. Three of these 4 were recently molted specimens from a laboratory colony and the other was a teneral specimen dug from its burrow in the field. Obviously none had ever flown. In studies of the same species Weaver and Sommers (1969, p. 338) also noted macroptreous teneral specimens, and in addition described behavior that accounts for the absence of macropterous individuals among non-teneral specimens: "When the cricket first transforms into the adult stage, the wrinkled, whitish hindwings extend for some distance beyond the posterior edge of the forewings ...... Usually within $24 \mathrm{hr}$ the hindwings are broken off at the base and eaten."

\footnotetext{
${ }^{1}$ This study was supported by NSF Grant GB-20749. Florida Agricultural Experiment Station Journal Series No. 4576.

${ }^{2}$ The three species are presently known as $A$. muticus (De Geer), but they will be given distinctive binomials in a paper now in press (Walker 1973).

Manuscript received by the editor October 9, 1972
} 
Prompted by these clues, I examined more than 20 "micropterous" specimens of each of the three species of Anurogryllus. All had wing stumps rather than short wings. I pulled with tweezers on one of the wings of an alcohol-preserved, non-teneral macropterous specimen. The wing tore loose with difficulty but left a stump like those of the "micropterous" specimens. Apparently all the specimens had once been macropterous, and the dimorphism in wing length in each of the three species is based on a dichotomy in wing deciduousness rather than a dichotomy in wing length in the newly formed adult.

\section{Discussion}

The term micropterous is inappropriate for crickets with the stumps of deciduous wings. The term dealated has been used for similar cases in other insects and seems appropriate here.

So far as now known, dealated Anurogryllus are originally macropterous rather than micropterous, but since wing shedding has not been observed in either of the West Indian species, the length of the shed wings is unknown. Furthermore the timing of shedding is not known for the West Indian species. One possibility is that it occurs only in teneral adults, as in the U. S. species. If this be the case, shedding the wings could depend on either the wings being weakly attached to the stumps or on wing-removing behavior or on both. If some or all teneral adults are competent both to retain and to shed their wings, their remaining macropterous or becoming dealates would most likely be an adaptive response to some aspect of their environment. For example a stimulus associated with dense population might inhibit wing shedding and promote emigration.

A second and contrasting possibility concerning the timing of wing shedding in West Indian Anurogryllus is that none sheds its wings while teneral and all or nearly all individuals disperse by flight before losing their wings. Situations analogous to this possibility occur in termites, ants, and perhaps certain zorapterans (Imms, 1957). I know of no case analogous to the first possibility (i.e. dimorphism with nonmigratory individuals shedding potentially functional wings). Certain Australian roaches of the genus Panesthia are apparently like the U. S. Anurogryllus - i.e. all individuals shed well-developed wings shortly after the final molt (Mackerras, 1970; p. 273).

The extent to which crickets other than Anurogryllus have deciduous wings is unknown. If such wings were characteristic of any of the species in which wing dimorphism has been carefully studied, 
they would have been reported. The only instances known to me of wing shedding in crickets other than Anurogryllus are in Gryllus. R. D. Alexander (personal communication ca. 1960, 1972) told me he had seen a Gryllus bimaculatus De Geer female pull off and eat the wings of a courting male. In handling living macropterous $G$. rubens Scudder, I have noted that the wings occasionally detach with only a slight pull. More recently I have tried pulling the wings from alcohol-preserved specimens of $G$. rubens. In both macropterous and micropterous individuals the wings were often easily detached. They tore just distal to the axillary sclerites and left stumps like those in Anurogryllus. These specimens had been freshly killed within the first week of adult life and had never flown. Of more than Ioo such specimens examined none was already dealated.

Two attributes of wing shedding that have probably contributed to its evolution are (I) it sometimes aids escape from predators (cf. G. rubens escaping from my grasp) and (2) it allows functionless or no-longer-functional wings to be eaten (cf. many insects, including crickets, eating their exuviae, apparently to nutritional advantage).

\section{SUMMARY}

In three species of Anurogryllus that are superficially dimorphic in wing length all "micropterous" individuals have the stumps of longer wings. The dimorphism is in the occurrence of wing shedding and is not known to correlate with a dimorphism in wing length.

\section{Alexander, R. D.}

\section{REFERENCES}

1961. Aggressiveness, territoriality, and sexual behavior in field crickets (Orthoptera: Gryllidae). Behaviour 17: 130-223.

1968. Life cycle origins, speciation, and related phenomena in crickets. Quart. Rev. Biol. 43 : 1-41.

IMMS, A. D.

1957. A general textbook of entomology, 9th ed. (rev. by O. W. Richards and R. G. Davies). Methuen, London. 886 p.

KenNedy, J. S., AND H. L. G. Stroyan

1959. Biology of aphids. Annu. Rev. Entomol. 4: 139-160.

MACKerRas, M. J.

1970. Blattodea (Cockroaches), p. 262-274, In Div. Entomol. Commonwealth Sci. Ind. Res. Org., Camberra, Insects of Australia. Melbourne Univ. Press, Melbourne. 
RichaRDS, O. W.

1961. An introduction to the study of polymorphism in insects, p. 1-10, In J. S. Kennedy (ed.), Insect polymorphism. Symp. No. 1, Royal Entomol. Soc. London.

WALKER, T. J.

1973. Systematics and acoustic behavior of U. S. and Caribbean shorttailed crickets (Orthoptera: Gryllidae: Anurogryllus). Ann. Entomol. Soc. Amer. 66: (in press).

Weaver, J. E., AND R. A. SOMmers

1969. Life History and habits of the short-tailed cricket, Anurogryllus muticus, in central Louisiana. Ann. Entomol. Soc. Amer. 62: 337-342. 

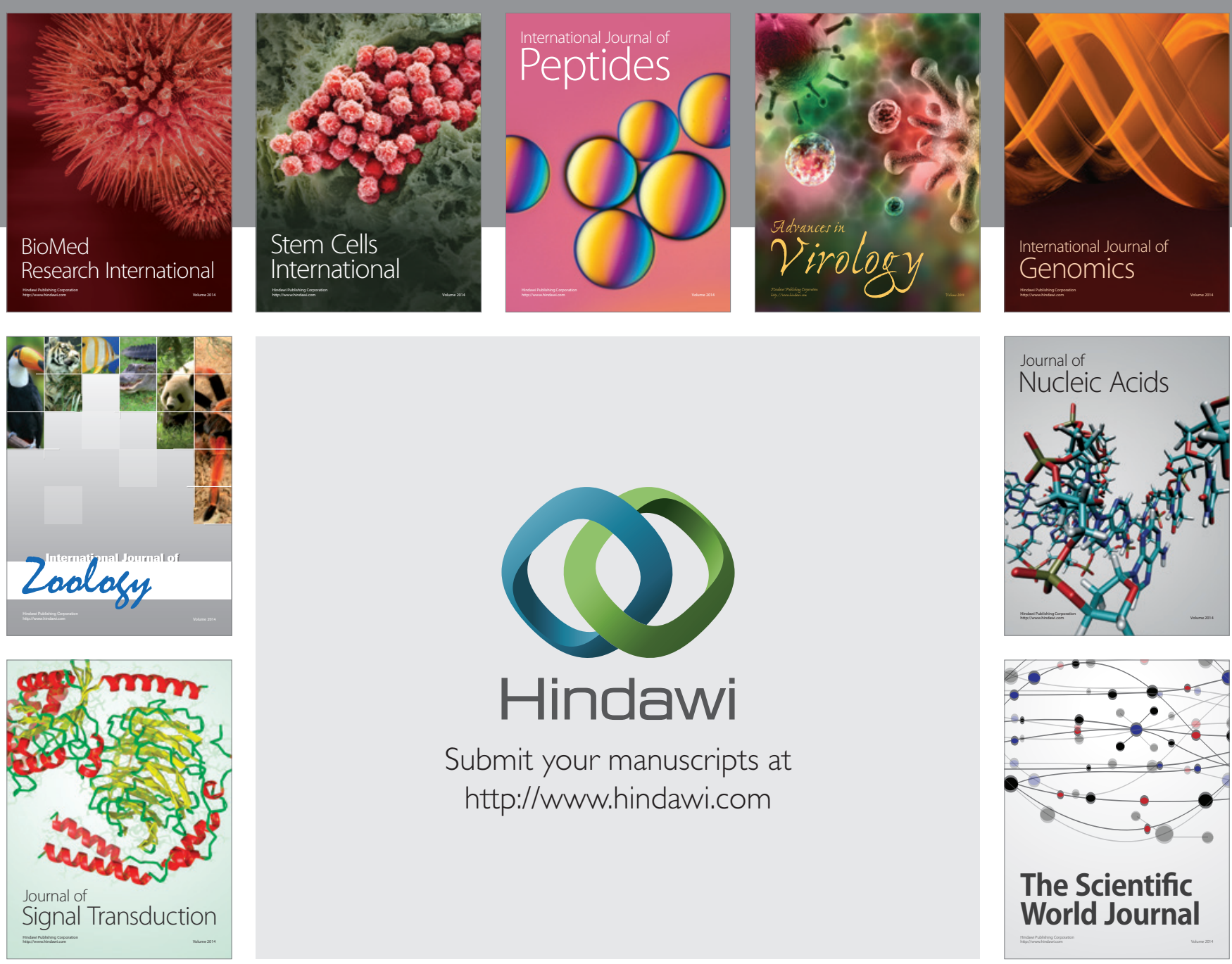

Submit your manuscripts at

http://www.hindawi.com
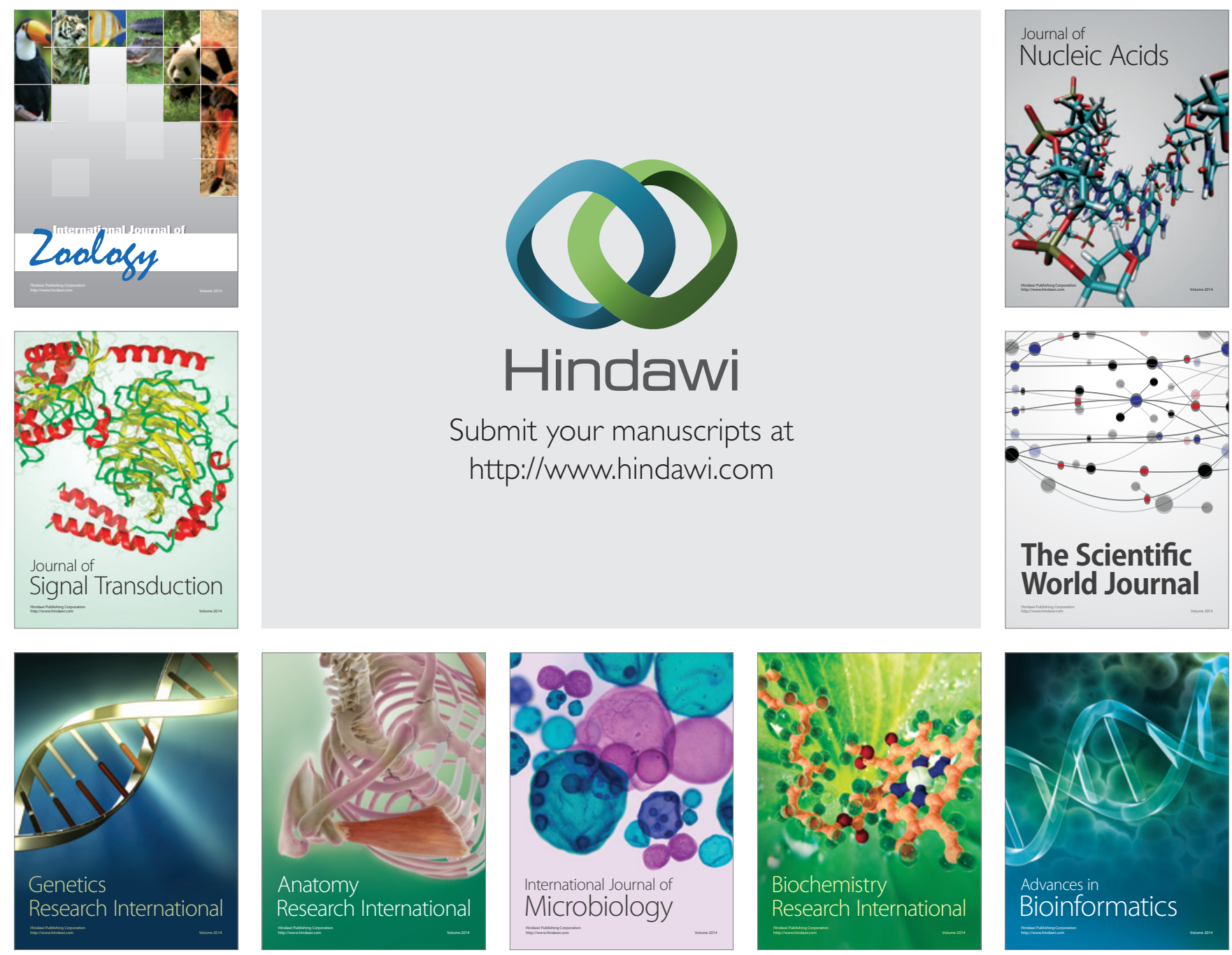

The Scientific World Journal
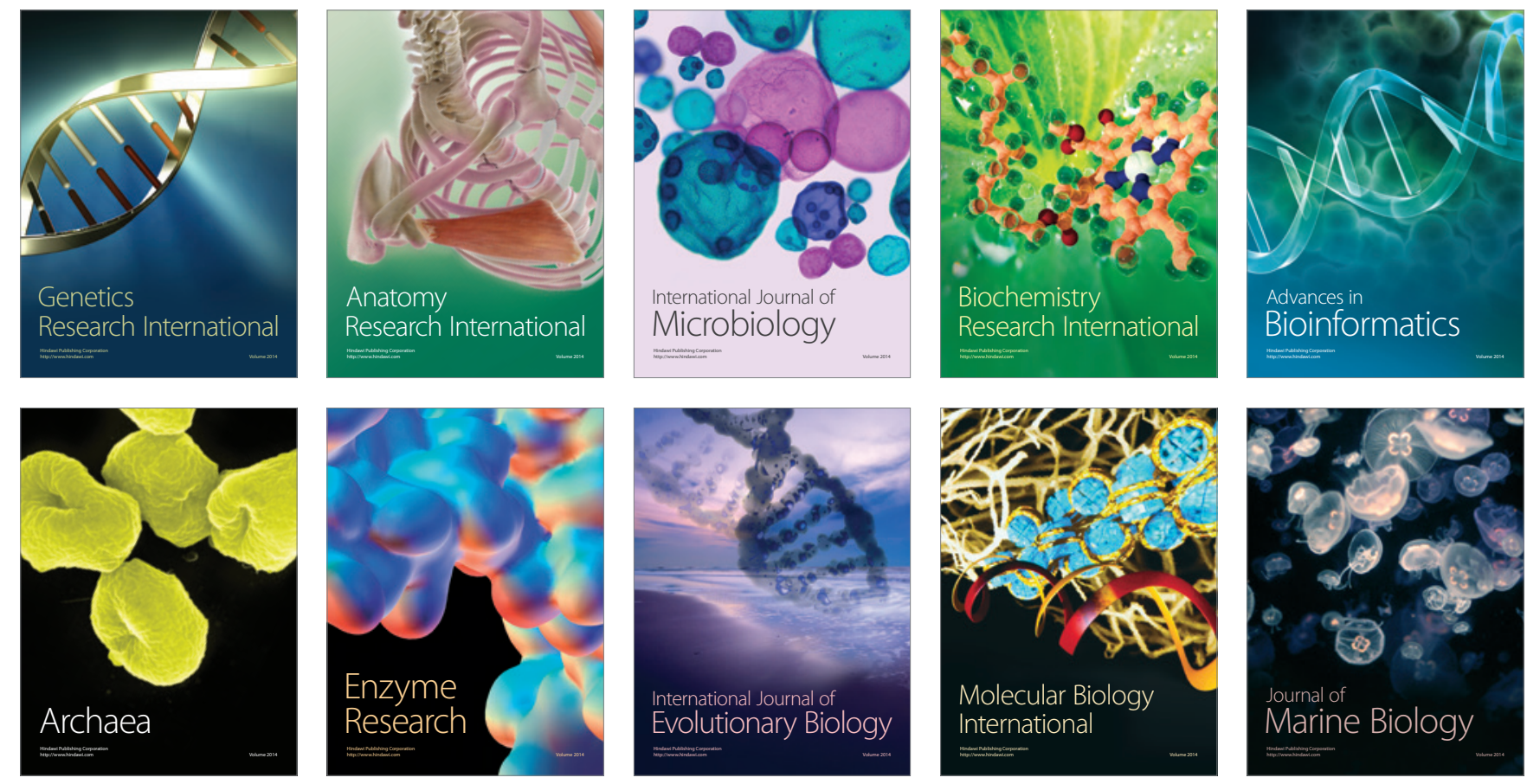